\title{
Dosage des amphétamines dans les cheveux, la salive et les urines
}

\section{Analysis of amphetamines in hair, oral fluid and urine}

\section{Christine MOORE(1)*, Michaël FELDMAN ${ }^{(2)}$, Nadia GIORGI(3), Wayne ROSS ${ }^{(3)}$, Edward HARRISON ${ }^{(2)}$, Dwain IRVAN ${ }^{(2)}$, David KUNTZ ${ }^{(2)}$, Alpana AGRAWAL ${ }^{(1)}$, Sumandeep RANA ${ }^{(1)}$, Michaël VINCENT ${ }^{(1)}$, James SOARES ${ }^{(1)}$}

\footnotetext{
(2) LabOne, Salt Lake City, Hayes Immunalysis Corporation, 829 Towne Center Drive, Pomona, CA 91767, USA

(3) Redwood Toxicology Laboratory, 3650 Westwind Boulevard, Santa Rosa, CA 95403, USA
(3)

*Corresponding Author: Christine MOORE, Immunalysis Corporation, 829 Towne Center Drive, Pomona, CA 91767, USA - Tel: 1-909 4820840 - Fax: 1-909 4820850 - E-mail: cmoore@immunalysis.com
}

(Reçu le 7 novembre 2005 ; accepté le 17 décembre 2005)

\section{RÉSUMÉ}

Des révisions proposées aux directives fédérales incluant l'utilisation potentielle des cheveux, de la salive ainsi que des urines pour le dépistage des conduites addictives en entreprise ont été publiés dans le registre fédéral en 2004. Cette étude a été conçue pour déterminer le taux de positivité de différents types d'échantillons dans une population toxicomane et dans une autre niant sa consommation de méthamphétamine. Cette étude a été menée sur 200 sujets, la moitié admettant une consommation de méthamphétamine, l'autre moitié la niant. Chaque sujet a donné un échantillon d'urine, de salive et de cheveux prélevés au moment de l'entrevue. Pour chaque sujet, des informations sur, leur consommation de stupéfiants, incluant la fréquence de consommation, leur appartenance ethnique, leur âge, leur sexe et la couleur de leurs cheveux ont été enregistrées. Les échantillons ont été analysés pour la méthamphétamine, l'ainphétamine, la 3-4 méthylendioxy-méthamphétamine (MDMA), son métabolite la méthylendioxy-amphétamine (MDA) et la

\section{SUMMARY}

Proposed revisions to the Federal guidelines, which include the potential use of hair and oral fluid, as well as urine, for workplace drug testing were published in the Federal Register in 2004. This study was designed to determine the positivity rate in various specimen types, both in a drug using population and a population denying methamphetanine use. The study enrolled 200 subjects, half of whom admitted to methamphetamine use, half who did not. Each subject provided a urine sample, an oral fluid and a hair specimen taken from the head at the time of interview. Information on drug use, including time of last use, frequency of use, ethincity, age, sex and hair color were recorded for each subject. The hair specimens were analyzed for methamphetamine, amphetamine, 3-4 methylenedioxy-methamphetamine (MDMA), its metabolite methylenedioxy-amphetamine (MDA) and methylenedioxy ethylamphetamine (MDEA). The oral fluid specimens were confirmed for the presence of methamphetamine, amphetamine, MDMA and MDA. Hair 
méthylendioxy éthylamphétamine (MDEA). Les échantillons de salive ont servi à valider la présence de méthamphétamine, d'amphétamine, de MDMA et de MDA. Les cheveux ont identifiés le plus grand nombre de toxicomanes dans les deux populations. Les urines ont permis d'identifier un plus grand nombre de sujets positifs que la salive. Bien que l'analyse des amphétamines dans les cheveux, la salive et les urines aient déjà été publiée, c'est la première étude où les trois matrices ont été collectées simultanément sur une population. toxicomane et analysées en suivant les directives fédérales.

\section{Introduction}

Methamphetamine acts as a stimulant, increasing physical activity and decreasing appetite, thereby contributing to lack of sleep, and weight loss. Long-term use of amphetamines can lead to malnutrition, as well as skin disorders, ulcers and vitamin deficiency. Other adverse effects include anxiety, violent behavior, hallucinations, addiction, paranoia, mental issues and even amphetamine induced psychosis and stroke. Methamphetamine has been the dominant drug in Southern California for many years. According to the 2000 National Household Survey on Drug Abuse, an estimated 8.8 million people ( $4 \%$ of the population) have tried methamphetamine at some time in their lives. Data from the 2000 Drug Abuse Warning Network (DAWN), which collects information on drug-related episodes from hospital emergency departments in 21 metropolitan areas, reported that methamphetamine-related episodes increased by $30 \%$ from approximately 10,400 in 1999 to 13,500 in 2000 , although there had previously been a significant decrease in methamphetamine-related episodes reported between $1997(17,200)$ and $1998(11,500)$.

\section{Hair}

Human hair grows at approximately $1-1.3 \mathrm{~cm}$ per month, and has been measured using various biomarkers $(1,2)$. Hair, due to its growth rate and stability, offers a much longer history of drug exposure than any other matrix. Hair has been increasingly chosen as a workplace test specimen, since, in contrast to urine, the collection is observed, and the possibility of adulteration or substitution of the specimens is reduced. There are many publications regarding the incorporation of methamphetamine into hair (3-5). Methamphetamine, amphetamine, 3-4 methylenedioxymethamphetamine (MDMA), its metabolite methylenedioxyamphetamine (MDA) and methylenedioxy ethylamphetamine (MDEA) are incorporated well into the hair shaft and have been detected and analyzed using established procedures $(6,7)$. For the screening of drugs in hair, both methanol and aqueous extraction procedures have been identified the highest number of drug users in both the admitted using population and those who denied use. Urine identified a higher number of positive subjects than oral fluid. While the analysis of amphetamines in hair, oral fluid and urine has been previously published, this is the first study where all three matrices were collected simultaneously from a drug using population, and analyzed according to the proposed Federal guidelines.

published; and for confirmatory analysis, gas chromatography with mass spectrometric detection is the preferred laboratory procedure (8).

\section{Oral Fluid}

Oral fluid is a useful specimen for the determination of recent drug use, and in some cases drugs found may be directly related to human performance. The main advantage of oral fluid over urine for workplace testing is that the collection of the specimen is observed, circumventing the additional expense of testing for adulterants in the laboratory $(9,10)$. There are several review papers regarding the analysis of drugs in oral fluid (11), and there are a number of published articles specific to the disposition of methamphetamine in plasma and saliva following administration (12,13). Generally, methamphetamine and its metabolite, amphetamine are predominantly detected in saliva. This study included MDMA and its metabolite, MDA, in the analysis.

\section{Urine}

Urine has been the accepted specimen for Federal Workplace Drug Testing for many years, however, problems with adulteration and substitution of samples, due to collection not being observed, have prompted the need for other, or "alternative" matrices. These problems caused laboratories to increase their workload by testing for dilution, nitrites, oxidants or other adulterants. Methamphetamine and amphetamine are currently analyzed in urine for the Federal program, although MDMA, MDA and MDEA are being added to the overall profile.

\section{Materials and Methods}

\section{Subjects}

The study enrolled 200 subjects, from the Drug and Alcohol Recovery Team (DART) in Fullerton, Orange County, Southern California. The study was approved under Immunalysis Institutional Review Board IRB \# 2004-05-001. All subjects participating in the study were made aware of the purpose of the study, and signed a consent form. While information on drug use, including time of last use, frequency of use, ethnicity, 
age, sex and hair color were recorded for each subject, names, addresses or other identifying information was not collected on the interview sheet. Complete anonymity was established during the sample collection and laboratory testing procedures. Each subject provided a urine sample, an oral fluid and a hair specimen taken from the head at the time of interview. Information on drug use, including time of last use, frequency of use, ethnicity, age, sex and hair color were recorded for each subject.

One hundred of the subjects admitted methamphetamine use in the recent past; the others denied drug use. The subjects ranged in age from 21 to 65 years old, and frequency of use ranged from daily to once a month.

\section{Experimental}

Hair and oral fluid screening kits were obtained from Immunalysis Corporation (Pomona, CA). The Methamphetamine Direct ELISA Kit (Catalog \# 2110480) was used for screening both the hair and oral fluid specimens according to the manufacturer's instructions. The urine specimens were screened using enzyme immunoassay with the Diagnostic Reagents, Inc. (DRI, Sunnyvale, CA) reagents for amphetamines (Catalog \# 0018). For confirmatory procedures, deuterated $d_{14}$-methamphetamine, $d_{11}$-amphetamine, $d_{5^{-}}$ MDMA, $d_{5}$-MDA and $d_{6}$-MDEA as internal standards as well as the unlabelled drug standards were obtained from Cerrilliant (Round Rock, TX). Solid phase mixed mode cation exchange - hydrophobic phase extraction columns (ZSDAU020, $200 \mathrm{mg}$ ) were obtained from United Chemical Technologies Inc. (Bristol, PA). The derivatizing agents trifluoroacetic anhydride (TFAA) and heptafluorobutyric anhydride (HFBA) were obtained from Pierce Chemical Co. (Rockford, IL). All solvents were HPLC grade or better, and all chemicals were ACS grade. The Toxi-Lab system was purchased from Varian Inc, Laguna Beach, CA.

\section{Hair}

\section{Sample preparation}

The hair was cut into small segments (3-5 mm), and an aliquot of $10 \mathrm{mg}$ was weighed. The hair was washed briefly with methanol ( $2 \mathrm{~mL} / 10 \mathrm{~min})$, the solvent was decanted and the hair was allowed to dry. To the hairs, $0.025 \mathrm{M}$ monobasic phosphate buffer (pH 2.7 with $0.1 \% \mathrm{BSA} ; 0.5 \mathrm{~mL}$ ) was added, the tubes were capped and incubated at $60^{\circ} \mathrm{C}$ for one hour. $0.5 \mathrm{M}$ dibasic phosphate buffer ( $\mathrm{pH} 9.0 ; 50 \mu \mathrm{L}$ ) was added to neutralize the acid environment and the liquids were transferred to corresponding clean glass tubes. All specimens, calibrators and controls were then diluted $1: 5$ by adding $400 \mu \mathrm{L}$ of phosphate buffer saline (PBS with $0.1 \% \mathrm{BSA}, \mathrm{pH} 7.0$ ) to $100 \mu \mathrm{L}$ of extract.

\section{Screening Assay}

An aliquot of the diluted hair extract $(20 \mu \mathrm{L})$, along with Horseradish peroxidase enzyme labeled methamphetamine derivative $(100 \mu \mathrm{L})$ was added to the individual micro-plate well coated with a methamphetamine specific antibody. After incubation (60 min, room temperature), the micro-plate wells were washed with deionized water $(6 \times 300 \mu \mathrm{L})$. Tetramethyl benzidine (TMB, $100 \mu \mathrm{L}$ ) was added to each well and the plate incubated in the dark for 30 minutes. The reaction was stopped using $1 \mathrm{~N}$ hydrochloric acid $(100 \mu \mathrm{L})$ and the plate read at $450 \mathrm{~nm}$ with a reference wavelength of $620 \mathrm{~nm}$. The sample size of $20 \mu \mathrm{L}$ of the diluted hair extract gave good separation at the screening cut-off concentration of $500 \mathrm{pg}$ of methamphetamine equivalents per milligram of hair.

A specimen was considered to be presumptively positive if it screened higher than the recommended cut-off of $500 \mathrm{pg} / \mathrm{mg}$.

\section{Confirmation Assay}

Presumptive positive samples identified using the screening assay were carried forward to confirmation using gas chromatography-mass spectrometry (GC/MS) operating in electron impact mode. The internal standard solution contained methamphetamine $-\mathrm{d}_{14}$ amphetamine $-d_{11}$, MDMA - $d_{5}$, MDA $-d_{5}$ and MDEA $-\mathrm{d}_{6}$. Low and high controls were also prepared. A separate aliquot of hair was weighed out $(2-10 \mathrm{mg})$ depending on the screening result) and methanol $(2 \mathrm{~mL})$ was added. The samples were incubated for 1-5 min at room temperature, then the methanol was discarded. Internal standard $(100 \mu \mathrm{L})$ was added to each calibrator, control or hair specimen. Methanol $(2 \mathrm{~mL})$ was added to the hairs and the tubes were heated at $75^{\circ} \mathrm{C}$ for 2 hours. The methanol was then transferred to clean glass tubes, and evaporated at $45^{\circ} \mathrm{C}$ under nitrogen until approximately $50-100 \mu \mathrm{L}$ was remaining. Phosphate buffer $(0.1 \mathrm{M}, \mathrm{pH} 6,2 \mathrm{~mL})$ was added to each tube.

Solid-phase mixed mode extraction columns (CleanScreen DAU) were placed into a vacuum extraction manifold. Each column was conditioned with methanol $(3 \mathrm{~mL})$, deionized water $(2 \mathrm{~mL})$ and $0.1 \mathrm{M}$ phosphate buffer ( $\mathrm{pH} 6.0 ; 2 \mathrm{~mL}$ ). The samples were allowed to flow through the columns using no vacuum. The columns were washed with deionized water $(2 \mathrm{~mL}), 0.1 \mathrm{M}$ hydrochloric acid $(2 \mathrm{~mL})$ and methanol $(3 \mathrm{~mL})$. The columns were allowed to dry at high pressure for 5 minutes. The drugs were finally eluted using fresh methylene chloride : isopropanol : ammonium hydroxide $(80: 20: 1.8 ; 2 \mathrm{~mL})$. The extracts were evaporated to dryness under nitrogen and reconstituted in heptafluorobutyric anhydride (HFBA, $50 \mu \mathrm{L}$ ) and ethyl 
acetate $(50 \mu \mathrm{L})$. The tubes were heated at $75^{\circ} \mathrm{C}$ for $15 \mathrm{~min}$, cooled and $50 \%$ ammonium hydroxide $(0.5$ $\mathrm{mL})$ was added. Following mixing, iso-octane $(100 \mu \mathrm{L})$ was added and the tubes centrifuged (3000 rpm; $5 \mathrm{~min}$ ). The tubes were frozen in dry ice to freeze the aqueous layer, and the upper organic layer was transferred to autosampler vials for analysis by GC/MS.

\section{Analytical Procedure (GC/MS)}

An Agilent Technologies 6890 gas chromatograph coupled to a 5973 mass selective detector (MSD) operating in electron impact mode was used for analysis (GC/MS). The gas chromatographic column was $1 \%$ phenyl-99\% methyl silicone DB-1, $0.20 \mathrm{~mm}$ ID, $0.33 \mu \mathrm{m}$ film thickness, $12 \mathrm{~m}$ length and the injection temperature was $200^{\circ} \mathrm{C}$. The injection mode was splitless. The oven was programmed from $70^{\circ} \mathrm{C}$; ramped at $15{ }^{\circ} \mathrm{C} / \mathrm{min}$ to $145^{\circ} \mathrm{C}$; then ramped at $45^{\circ} \mathrm{C} / \mathrm{min}$ to $280^{\circ} \mathrm{C}$. The transfer line was held at $280^{\circ} \mathrm{C}$. The ions monitored for each internal standard and drug are shown in Table I.

The limit of quantitation of the procedure was 20 $\mathrm{pg} / \mathrm{mg}$ for amphetamine and $40 \mathrm{pg} / \mathrm{mg}$ for the other analytes. The linearity range was from $20-40,000$ $\mathrm{pg} / \mathrm{mg}$ and the precision at the cut-off was less than $3.0 \%$ for all analytes. A sample was not considered positive, unless it contained at least $300 \mathrm{pg} / \mathrm{mg}$ of methamphetamine, and also contained amphetamine at equal to or greater than $50 \mathrm{pg} / \mathrm{mg}$.

Table I : lons monitored in the SIM profile using gas chromatography-mass spectrometric (GC/MS) analysis.

\begin{tabular}{|l|l|l|}
\hline & Quantitation Ion & Qualifying lons \\
\hline Methamphetamine & 254 & 210,118 \\
\hline Methamphetamine $-\mathrm{d}_{\mathrm{u}}$ & 261 & 213 \\
\hline Amphetamine & 240 & 118,91 \\
\hline Amphetamine $-\mathrm{d}_{\mathrm{u}}$ & 244 & 128 \\
\hline MDMA & 254 & 210,162 \\
\hline MDMA $-\mathrm{d}_{s}$ & 258 & 213 \\
\hline MDA & 162 & 240,375 \\
\hline MDA $-\mathrm{d}_{s}$ & 167 & 244 \\
\hline MDEA & 268 & 240,162 \\
\hline MDEA $-\mathrm{d}_{\mathrm{s}}$ & 274 & 244 \\
\hline
\end{tabular}

\section{Oral fluid}

\section{Sample Preparation}

The oral fluid specimens were collected using a Quantisal ${ }^{\mathrm{TM}}$ collection device (Immunalysis, Pomona $\mathrm{CA}$ ). When the absorbent collection pad had absorbed $1 \mathrm{~mL}$ of neat oral fluid (+-10\%), a blue dye was visible in the indicator window on the plastic stem of the collection pad. The pad was placed in a polypropylene transport tube containing $3 \mathrm{~mL}$ of extraction buffer solution, capped and taken to the laboratory.

\section{Screening Assay}

An aliquot $(10 \mu \mathrm{L})$ of the oral fluid + buffer was added to the micro-plate wells for analysis following the protocol described above for the hair specimens, and according to the manufacturer's instructions in the package insert. A specimen was considered to be presumptively positive if it screened higher than the recommended cut-off of $50 \mathrm{ng} / \mathrm{mL}$ of methamphetamine equivalents.

\section{Confirmation Assay}

Presumptive positive specimens were confirmed using gas chromatography-mass spectrometry (GC/MS). Calibrators and control were prepared in $25 \%$ synthetic saliva and $75 \%$ Quantisal $^{\mathrm{TM}}$ buffer. For the specimens, $1 \mathrm{~mL}$ was removed from the Quantisal ${ }^{\mathrm{TM}}$ collector. Internal standard $(200 \mu \mathrm{L})$ containing deuterated $\mathrm{d}_{6}$ amphetamine and $\mathrm{d}_{9}$ - methamphetamine was added. Low and high controls were included in each confirmation batch. Concentrated ammonium hydroxide $(150 \mu \mathrm{L})$ and 1-chlorobutane $(3 \mathrm{~mL})$ were added to each sample. The specimens were mixed for 10 minutes and then centrifuged. The top layer was transferred to glass screw cap tubes, trifluoroacetic anhydride (TFAA, $100 \mu \mathrm{L}$ ) was added, and the tubes were capped. Following mixing, the samples were heated at $70^{\circ} \mathrm{C}$ for $15 \mathrm{~min}$ and evaporated to dryness. The specimens were reconstituted in ethyl acetate $(50 \mu \mathrm{L})$ and transferred to auto-sampler vials for analysis using GC/MS. The ions monitored were 144 and 123 for deuterated amphetamine $\left(d_{6}\right) ; 140,118$ and 91 for amphetamine; 161 and 123 for deuterated methamphetamine $\left(\mathrm{d}_{9}\right) ; 154,118$ and 110 for methamphetamine. MDMA and MDA were not detected in any of the samples. MDEA was not monitored in the oral fluid specimens.

\section{Analytical Procedure (GC/MS)}

A Shimadzu QP5000 instrument was used for analysis. The column was a HP1-MS (30 m length $\times 0.25 \mathrm{~mm}$ diameter $\times 0.25 \mu \mathrm{m}$ film thickness). The injector was operated in splitless mode and the injection temperature was $200^{\circ} \mathrm{C}$. The oven was programmed from $70^{\circ} \mathrm{C}$ to $180^{\circ} \mathrm{C}$ at $20^{\circ} \mathrm{C} / \mathrm{min}$, ramped at $40^{\circ} \mathrm{C} / \mathrm{min}$ to $240^{\circ} \mathrm{C}$ and held for $1.2 \mathrm{~min}$. The transfer interface temperature was $280^{\circ} \mathrm{C}$. The instrument was operated in electron impact mode. The limit of quantitation was $15 \mathrm{ng} / \mathrm{mL}$ for amphetamine and methamphetamine; and the upper limit of linearity was $2500 \mathrm{ng} / \mathrm{mL}$ for amphetamines; $5000 \mathrm{ng} / \mathrm{mL}$ for methamphetamine of neat oral fluid equivalents. A sample was not considered positive, unless it contained at least $50 \mathrm{ng} / \mathrm{mL}$ of methamphetamine, and also contained amphetamine at equal to or greater than the limit of detection of the assay. 


\section{Urine}

The urine specimens were screened using Diagnostic Reagents, Inc. (DRI) EIA assay for amphetamines at a cut-off of $1000 \mathrm{ng} / \mathrm{mL}$. The DRI assays were performed on the Hitachi 717, a fully automated chemistry analyzer. Specimens screening positively were confirmed using the Toxi-Lab thin-layer chromatography system (Toxi-Lab, Inc). thin-layer chromatography system, for the confirmation of amphetamine and methamphetamine, according to the manufacturer's protocol (14). The detection limits for amphetamines and methamphetamine were 400 and $200 \mathrm{ng} / \mathrm{mL}$ respectively.

\section{Results and discussion}

Methamphetamine use has become a major problem among many communities, frequently associated with violence among men and women (15). As far back as 1995, Kipke et al. reported that $62 \%$ of Los Angeles street youth admitted taking methamphetamine, in fact it was the second most popular drug after marijuana (16). In a study of juvenile arrestees reported in 2002, $11.9 \%$ of girls and $9.2 \%$ of boys reported using amphetamines, while $12.4 \%$ of girls and $8.5 \%$ of boys reported the use of crystal methamphetamine specifically. Crystal methamphetamine or "crank" has longer lasting effects and is less expensive than heroin or cocaine. The ethnicity of the subjects was approximately equal through African American, Hispanic and Caucasian juveniles (17). More recently, methamphetamine has been reported as the drug of choice in communities of gay and bisexual men, where it has been associated with high-risk behaviors. It was shown to be a commonly used drug among these groups in New York City where it is often combined with other drugs that may increase its risks and adverse health consequences. The reports indicate that methamphetamine is widely used by men across all age groups, educational level, race and HIV status, but that rates of methamphetamine use can be reduced with methamphetamine dependence treatment $(18,19)$.

In our study, hair and oral fluid specimens were considered positive when they were confirmed using GC/MS procedures at or above the levels dictated by the proposed Federal guidelines (20). The results for the positive specimens are shown in Table II.

Self-reported Drug Users: In the self-reported drug using population, 16 individuals were not positive by any specimen type. Of the remaining 84 subjects found to be positive, $56(66.6 \%)$ were positive via the hair test, 52 (61.9\%) using urinalysis and $48(57.1 \%)$ via oral fluid.
Table II : Positivity by matrix from a population admitting methamphetamine use, and from subjects denying methamphetamine use.

\begin{tabular}{|l|l|l|l|}
\hline & $\begin{array}{l}\text { Self-reported } \\
\text { Drug Users }\end{array}$ & $\begin{array}{l}\text { Self-reported } \\
\text { Non-Drug Users }\end{array}$ & Overall \\
\hline All matrices negative & 16 & 72 & 88 \\
\hline All matrices positive & 26 & 5 & 31 \\
\hline + Hair only & 20 & 15 & 35 \\
\hline + Hair and oral fluid & 3 & 1 & 4 \\
\hline + Hair and urine & 7 & 5 & 12 \\
\hline + Urine only & 9 & 1 & 10 \\
\hline + Oral fluid and urine & 10 & 1 & 11 \\
\hline + Oral fluid only & 9 & 0 & 9 \\
\hline Total & 100 & 100 & 200 \\
\hline
\end{tabular}

Self-reported Non-drug Users: In the self-reported non-drug taking population, 25 of 28 subjects $(89.2 \%)$ who tested positively had a positive hair test, while only $12(42.8 \%)$ were positive through urinalysis and 7 (25\%) were positive via oral fluid. Both urine and oral fluid were only able to identify a low number of methamphetamine users, urine identified twelve subjects; oral fluid identified seven, but hair identified 26 individuals as positive, more than twice as many subjects as urine, and more than three times as many subjects as oral fluid. This is in agreement with other publications, indicating hair identifies more positive drug users than the other specimens tested (21).

Overall: Eighty-eight (88) of the 200 subjects were negative in all sample types, but of the 112 individuals who were positive in at least one matrix, $82(73.2 \%)$ had a positive hair assay, while only 64/112 (57.1\%) had a positive urine and 55/112 (49.1\%) provided a positive oral fluid test. Hair identified $56 \%$ of admitted methamphetamine users; urine detected $52 \%$ of users, and oral fluid identified $48 \%$ of subjects admitting methamphetamine use. Overall, the hair identified 18 more specimens than urine, and 27 more samples than oral fluid (Figure 1).

Correlation: It is difficult to determine whether a correlation exists between the frequency of dose reported

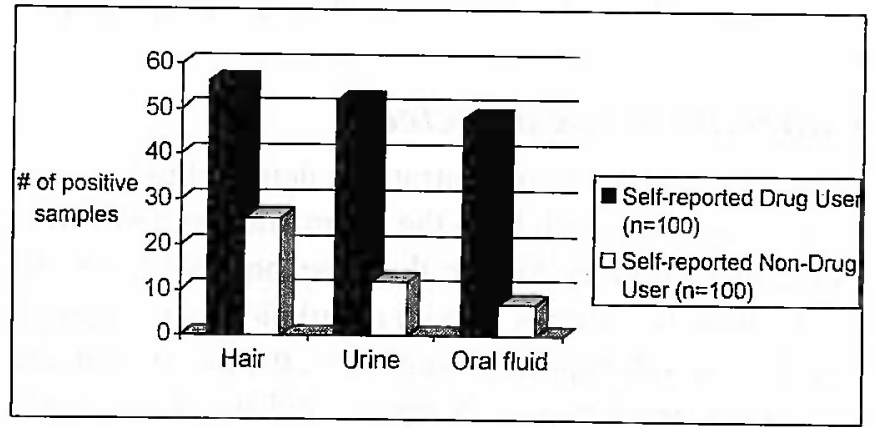

Figure 1 : Number of positive tests in each population $(n=200)$. 
by the subjects and the amounts of drug and metabolites detected in the specimens. Variation in the amount of drug, purity of drug, time after sampling, as well as the truthfulness of subjects all affect the outcome. However, within this study group, it is clear that hair is the best specimen to test in order to identify the highest number of drug users, whether or not self-reported. In general, urine identified a higher number of drug users than oral fluid in both populations.

Hair Color and Ethnicity: The hair color and ethnicity of the subjects was recorded at interview. The state of the art in hair testing is that it is most likely the melanin content of hair is critical in determining the basic drug content in hair, not ethnicity. In our subjects, the predominant hair color was black across all ethnic types (55\%). Dark brown and gray accounted for approximately $20 \%$ each of the subjects, with only a few subjects having red, blonde, or light brown hair. Since there was little variation in hair color and melanin content, it was difficult to form any conclusions on the effect of pigmentation on methamphetamine incorporation.

The ethnicity of the subjects also had little effect on the identification of methamphetamine users. Hair identified a much higher number of drug users than either oral fluid or urine across all ethnicities. A breakdown of the demographics from the subjects testing positively showed that males accounted for $66 / 112$ (58.9\%) of the positive subjects; females for $41.1 \%$.

Whites accounted for the highest number of positives in all specimen types, with 43 of 82 hair specimens $(52.4 \%)$ being positive, 34 of $64(53.1 \%)$ of urines and 33 of $55(60 \%)$ of oral fluids. African American subjects accounted for 18 of $82(21.9 \%)$ of all hair positives, 10/64 (15.6\%) of urines and 5/55 (9\%) of oral fluid samples. In the Hispanic population, all three matrices were similar in detection rate. Hair accounted for 11 of $82(13.4 \%)$, urine for $9 / 64(14 \%)$ and oral fluid for $9 / 55(16.3 \%)$ of the total positive samples. Finally, those describing themselves as "other" accounted for $12.1 \%$ of the hair positives, $17.1 \%$ of the urine positives, and $14.5 \%$ of the oral fluid positive samples (Figure 2).

\section{Concentrations detected}

Hair: The range of concentrations detected in hair was extremely wide, with both the mean and median values being substantially higher than the proposed cut-offs for regulatory samples in both populations $(0.3 \mathrm{ng} / \mathrm{mg})$. Among the self-reported drug users, the mean methamphetamine level was $13.8 \mathrm{ng} / \mathrm{mg}$ and the median was $7.8 \mathrm{ng} / \mathrm{mg}$. For amphetamine, the levels were 1.0 $\mathrm{ng} / \mathrm{mg}$ for the mean, and $0.53 \mathrm{ng} / \mathrm{mg}$ for the median

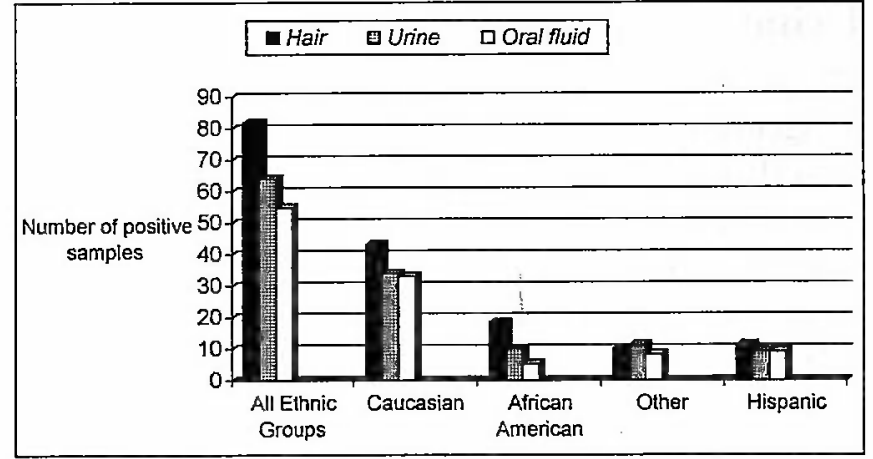

Figure 2 : Number of positive specimens separated by ethnic group.

value.

In the population reporting no use of methamphetamine, the average levels were lower than in the self-reported population. The mean methamphetamine level was $11 \mathrm{ng} / \mathrm{mg}$; median value was $6.8 \mathrm{ng} / \mathrm{mg}$. The mean amphetamine level was $0.72 \mathrm{ng} / \mathrm{mg}$; median concentration $0.35 \mathrm{ng} / \mathrm{mg}$.

Figure 3 shows the extracted ion chromatogram of a hair specimen taken from a subject admitting to methamphetamine use twice a week. The system would only allow 6 extracted ion chromatograms to be shown on one page, but the other ions were collected for each sample and used in the determination of positivity according to accepted GC/MS validation protocols. The hair contained $8.8 \mathrm{ng} / \mathrm{mg}$ of methamphetamine and $0.24 \mathrm{ng} / \mathrm{mg}$ of amphetamine.

Oral fluid and Urine: In our study, the positive rates for

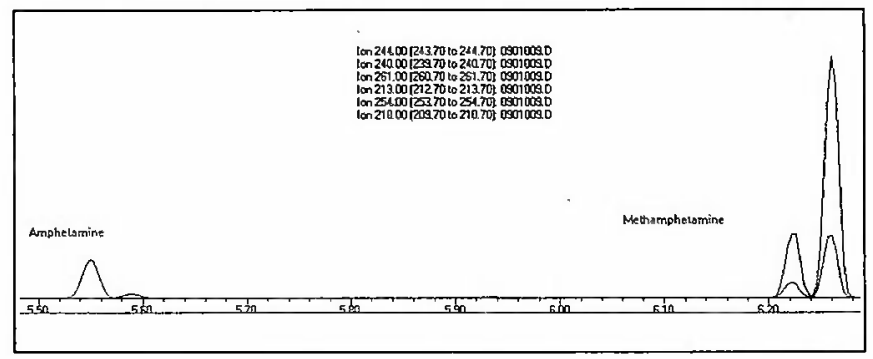

Figure 3 : Hair specimen from Subject ID \#3

Amphetamine: $0.24 \mathrm{ng} / \mathrm{mg}$

Methamphetamine: $8.8 \mathrm{ng} / \mathrm{mg}$.

oral fluid and urine were similar within each population of admitted drug users and the non-drug using subjects. The range of concentrations measured in oral fluid was from the low nanograms per milliliter ( $\mathrm{ng} / \mathrm{mI}$ ) to over $5000 \mathrm{ng} / \mathrm{mL}$ of methamphetamine and over $500 \mathrm{ng} / \mathrm{mL}$ of amphetamine. Obviously the timing of collection following recent methamphetamine use is a factor in 
the level detected. As expected, the highest levels of methamphetamine were detected in subjects admitting to very recent methamphetamine use.

Four individuals had methamphetamine values of over $5000 \mathrm{ng} / \mathrm{mL}$ with associated high amphetamine levels. All admitted to using methamphetamine in the recent past. Three of the four had used on the day of collection, but one stated his last use was three days before collection and he only used once a month. The corresponding hair results from the other subjects are shown in Table III. No specimens contained MDMA and MDA, and no samples showed the presence of amphetamine alone.

Figure 4 shows the chromatogram obtained from the analysis of the oral fluid of a subject admitting to daily methamphetamine use. The amphetamine concentra- tion was $108 \mathrm{ng} / \mathrm{mL}$ and methamphetamine level was $233 \mathrm{ng} / \mathrm{mL}$. His urine sample was also positive, and his hair tested positively at concentrations of $2.4 \mathrm{ng} / \mathrm{mg}$ and $0.33 \mathrm{ng} / \mathrm{mg}$ for methamphetamine and amphetamine respectively.

\section{Acknowledgements}

We are grateful to Ms. Toby Evans for facilitating subject access at the Drug and Alcohol Recovery Team (DART) and to Russell Munford (Immunalysis Corporation) for the collection of all the specimens. Many thanks are due to Michelle Nguyen and Erma Abolencia for all the immunoassay testing of oral fluid and hair samples at Immunalysis Corporation.

Table III : Results of hair specimens from subjects having greater than $5000 \mathrm{ng} / \mathrm{mL}$ of methamphetamine in their oral fluid samples.

\begin{tabular}{|l|l|l|l|l|l|}
\hline & & Oral Fluid (ng/ml) & & Hair (ng/mg) & \\
\hline Sample ID & Drug Use & Methamphetamine & Amphetamine & Methamphetamine & Amphetamine \\
\hline 57 & $1 \times$ month & $>5000$ & 144 & Not detected & Not detected \\
\hline 18 & $3 \times$ week & $>5000$ & 627 & 32.6 & 2.88 \\
\hline 33 & $2 \times$ week & $>5000$ & 454 & 3.9 & 0.26 \\
\hline 40 & $2 \times$ day & $>5000$ & 482 & 9.4 & 0.40 \\
\hline
\end{tabular}

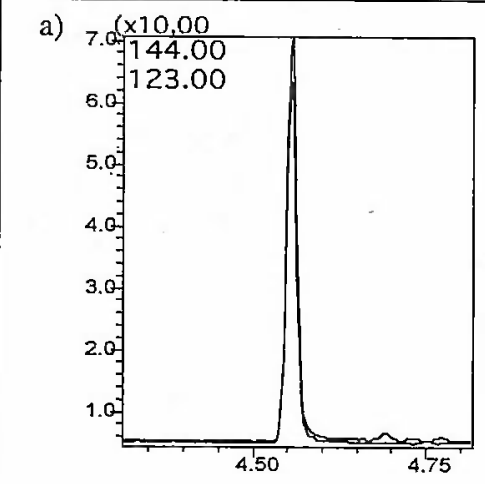

c)

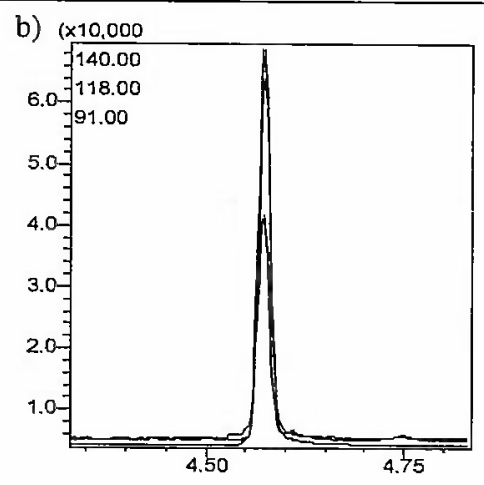

d)

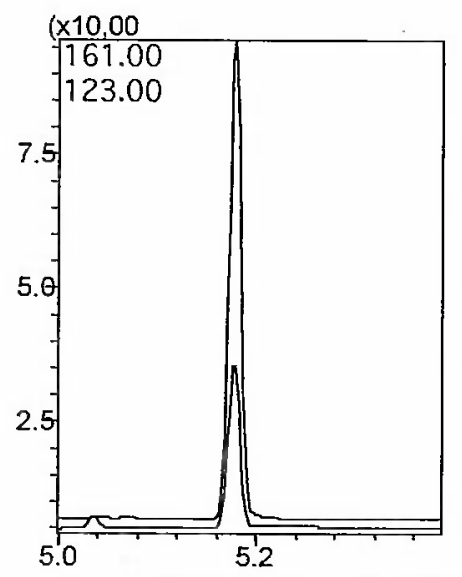

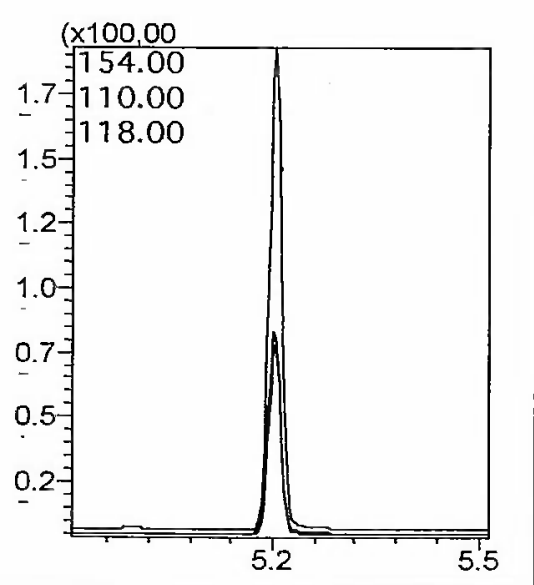

Figure 4 : Oral fluid specinen from subject ID \#32
a. D5-amphetanine
b. Amphetamine (108 $\mathrm{ng} / \mathrm{mL})$
c. D6-methamphetamine
d. Methamphetamine (233 $\mathrm{ng} / \mathrm{mL})$. 


\section{References}

1. N. Miyazawa and T. Uematsu. Analysis of ofloxacin in hair as a measure of hair growth and as a time marker for hair analysis. Ther Drug Monit. 14: 525-528 (1992).

2. T. Uematsu, A. Mizuno, S. Nagashima, A. Oshima and M. Nakamura. The axial distribution of nicotine content along hair shaft as an indicator of changes in smoking behaviour: Evaluation in a smoking cessation programme with or without the aid of nicotine chewing gum. $\mathrm{Br} \mathrm{J}$ Clin Pharmacol. 36: 665-669 (1995).

3. A. Miki, H. Katagi and H. Tsuchihashi. Determination of methamphetamine and its metabolites incorporated in hair by column-switching liquid chromatography-mass spectrometry. J Anal Toxicol. 27(2): 95-102 (2003).

4. N. Takayama, R. Iio, S. Tanaka, S. Chinaka and K. Hayakawa. Analysis of methamphetamine and its metabolites in hair. Biomed Chromatogr. 17(2-3): 74-82 (2003).

5. D.L. Lin, R.M. Yin, H.C. Liu, C.Y. Wang and R. H. Liu. Deposition characteristics of methamphetamine and amphetamine in fingernail clippings and hair sections. J Anal Toxicol. 28(6): 411-417 (2004).

6. M. Nishida, A. Namera, M. Yashiki and T. Kojima. Routine analysis of amphetamine and methamphetamine in biological materials by gas chromatography-mass spectrometry and on-column derivatization. J Chromatogr B Analyt Technol Biomed Life Sci. 789(1): 65-71 (2003).

7. G.A. Cooper, D.L. Allen, K.S. Scott, J.S. Oliver, J. Ditton and I.D. Smith. Hair analysis: self-reported use of "speed" and "ecstasy" compared with laboratory findings. J Forensic Sci. 45(2): 400-406 (2000).

8. L. Skender, V. Karacic, I. Brcic and A. Bagaric. Quantitative determination of amphetamines, cocaine, and opiates in human hair by gas chromatography/mass spectrometry. Forensic Sci Int. 125(2-3): 120-126 (2002).

9. B.D. Paul. Six spectroscopic methods for detection of oxidants in urine: implication in differentiation of normal and adulterated urine. J Anal Toxicol. 28(7): 599-608 (2004).

10. F.M. Urry, G. Komaromy-Hiller, B. Staley, D.K. Crockett, M. Kushnir, G. Nelson and R.E. Struempler. Nitrite adulteration of workplace urine drug-testing specimens. I. Sources and associated concentrations of nitrite in urine and distinction between natural sources and adulteration. J Anal Toxicol. 22(2): 89-95 (1998).

11. N. Samyn, A. Verstraete, C. van Haeren and P. Kintz. Analysis of drugs of abuse in saliva. Forens Sci Rev. 11(1): 1-16 (1999).
12. R.J. Schepers, J.M. Oyler, R.E. Joseph, E.J. Cone, E.T. Moolchan and M.A. Huestis. Methamphetamine and amphetamine pharmacokinetics in oral fluid and plasma after controlled oral methamphetamine administration to human volunteers. Clin Chem 49(1): 121-132 (2003).

13. N. Samyn, G. De Boeck, M. Wood, C.T. Lamers, D. De Waard, K.A. Brookhuis, A.G. Verstraete and W.J. Riedel. Plasma, oral fluid and sweat wipe ecstasy concentrations in controlled and real life conditions. Forensic Sci Int. 128(1-2): 90-97 (2002).

14. Toxi-Lab Instruction Manual, Analytical System, Inc., Laguna Hills, CA (1983) - Cat. No. 181AB

15. J.B. Cohen, A. Dickow, K. Horner, J.E. Zweben, J. Balabis, D. Vandersloot and C. Reiber. Abuse and violence history of men and women in treatment for methamphetamine dependence. Am J Addict. 12(5): 377-385 (2003).

16. M.D. Kipke, S. O'Connor, R. Palmerand R.G. MacKenzie. Street youth in Los Angeles. Profile of a group at high risk for human immunodeficiency virus infection. Arch Pediatr Adolesc Med. 149(5): 513-519 (1995).

17. J.Y. Kim and M. Fendrich. Gender differences in juvenile arrestees' drug use, self-reported dependence, and perceived need for treatment. Psychiatr Serv. 53(1): 70-75 (2002).

18. P.N. Halkitis, K.A. Green and P. Mourgues. Longitudinal Investigation of Methamphetamine Use among Gay and Bisexual Men in New York City: Findings from Project BUMPS. J Urban Health. 82(1 Suppl 1): i18-i25 (2005).

19. J.A. Peck, C.J. Reback, X. Yang, E. Rotheram-Fuller amd S. Shoptaw. Sustained reductions in drug use and depression symptoms from treatment for drug abuse in methamphetamine-dependent gay and bisexual men. J Urban Health. 82(1 Suppl 1): i100-i108 (2005)

20. Department of Health and Human Services. Substance Abuse and Mental Health Services Administration. Proposed Revisions to Mandatory Guidelines for Federal Workplace Drug testing Programs. Federal Register 69(71): (2004)

21. M. Fendrich, T.P. Johnson, J.S. Wislar, A. Hubbell and V. Spiehler. The utility of drug testing in epidemiological research: results from a general population survey. Addiction. 99(2): 197-208 (2004). 